\title{
THE EFFECTS OF THE IMPLEMENTATION OF 2013 CURRICULUM TO STUDENTS' ENGLISH LEARNING ACHIEVEMENT AT SMAN 1 ALLA' ENREKANG
}

\author{
Nur Humairatul Ulya A. \\ English Education Department of UIN Alauddin Makassar \\ nurhumairatul.ulya@gmail.com
}

\begin{abstract}
The objective of this research was to find out whether or not the implementation of 2013 curriculum give effects to the development of students' English achievement at the second grade of SMAN 1 Alla' Enrekang. This research was a descriptive design using observation, questionnaires, and documentation conducted at the second year of SMAN 1 Alla' Enrekang class MIA 1 and IIS 2 in academic year of 2014/2015. The total sample of this research consisted of 61 students. The data were collected through observation in the class when the learning process conducted to know how the implementation of the 2013 curriculum and questionnaire as supporting data from observation while documentation to know the students' learning achievement that was analyzed by descriptive and statistic. The data analysis and interpretation indicated (1) The implementation of the 2013 curriculum in SMAN 1 Alla' Enrekang was good. (2) Learning achievement using the 2013 curriculum and KTSP was good. (3) There is no difference between students' English learning achievement using different curriculum. It could be concluded that the learning achievement was not only influenced by the curriculum, but also many other factors for example the teachers or the facilities. In other words, the 2013 curriculum did not give effect to students' English learning achievement.
\end{abstract}

KEY WORDS: the 2013 curriculum, students' English learning achievement.

\section{A. INTRODUCTION}

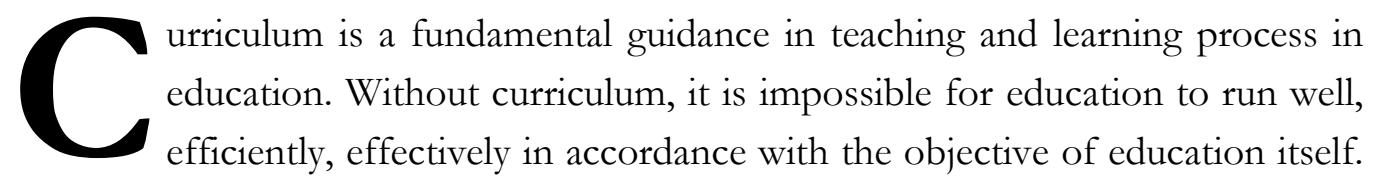

The successfulness or unsuccessfulness of education is determined by the good curriculum. Therefore, curriculum has a central and strategic position in all of the education process. Curriculum directs all form of educational activity to reach the objective of education. The purpose of education itself, as mentioned in the Educational Act No 20 in 2003 about Educational System said that the objective of 
Nur Humairatul Ulya A, The Effects of The Implementation of 2013 Curriculum to Students'...

education is to develop the students' potential to become of faithful and piety to the Almighty God, to have good morals, knowledgeable, healthy, skillful, creative, independent, and become democratic citizen and accountable (Fadlillah, 2014: 13). These goals cannot be achieved without curriculum.

Curriculum likes spears in education. So that is why, response education to development of the time is change the curriculum. Therefore, changes in the curriculum are something that is unavoidable changes. This change is a consequence and implication of the changes of political system, socio-cultural, economic, and development of science and technology. The curriculum will continually change and it cannot be prevented, for preparing learners who are able to competitive in the future with all the advances in science and technology.

The 2013 curriculum is curriculum that is implemented in the academic year 2013/2014. This curriculum is developing from previous curriculum. The emphasis in this curriculum is the increase and balance of soft skill and hard skill that include aspects of affective, psychomotor, and cognitive (Fadlillah, 2014: 16). In 2013 curriculum have been instilled the values that reflected in the attitudes that can be directly proportional with skill that acquired by the students through knowledge in the school. The 2013 curriculum is intended to improve the knowledge, skills, and attitudes of learners, where learners must be active in learning process and the teachers must be creative in providing and introducing the material.

The curriculum change is aimed to improve the quality of the students learning along with the development of the times. The implementing of 2013 curriculum is very interested to discuss, as the curriculum can determine the students' learning achievement. Learning Achievement is a result of the student learning activity. In 2013 curriculum aims to balance the attitude, skill, and knowledge to built soft skills and hard skills. This is needed because of the fact now days, students competence in affective is lower than their cognitive competence. They do not respect to their teachers. So that is why, if this curriculum implemented, how it may give influence to the students. According to Johnson and Posner in Hamalik (2008), curriculum should not view as an activity, but it focuses on the intended learning outcomes. This state emphasizes the changes of the way to look the curriculum, from curriculum as a means, become curriculum as the last objectives, or the ends.

The 2013 curriculum is government policy that should be applied in schools, especially in formal schools in Indonesia. No exception to SMA Negeri 1 Alla' where researcher conducted the research. However, the government is not consistent in running this curriculum. Now, there is policy that a school may go back to the previous curriculum if it cannot apply the 2013 curriculum well. Although the 
schools can use the previous curriculum, in this case KTSP, but SMA Negeri 1 Alla' is still continuing the 2013 curriculum. SMA Negeri 1 Alla' is a school that located in the Alla' District, Enrekang Regency. This school has been become the top school in the area. As with other schools, before 2013 curriculum applied, first this school applied KTSP. To see the mean of students' learning achievement in KTSP with student learning achievement in 2013 curriculum, the researcher found out the effect of the implementation of 2013 curriculum. After implemented for one year, this curriculum has gained a lot of problems in its application. Currently there are only a few schools that implement the curriculum in 2013 due to the poor preparation of other schools to implement this curriculum. Then, the researcher researched the effects of the implementation of 2013 curriculum to students' English learning achievement in this case is to measure the increase of learning achievement from the previous curriculum (KTSP).

Furthermore, the research problem of this research was "does the implementation of 2013 curriculum give effects to the development of students' English achievement in the second grade of SMAN 1 Alla' Enrekang??. Then, the research objective was to find out whether or not the implementation of 2013 curriculum give effects to the development of students' English achievement at the second grade of SMAN 1 Alla' Enrekang. In addition, this research was beneficial in context for the students (they will know the effect of implementing 2013 curriculum to themselves in this case in learning achievement), the teachers (they can know how to implement the 2013 curriculum), the school or the other schools (the school can be an example and the other schools may use 2013 curriculum when it has positive effect to the quality of the students). Finally, this study was focus on implementation of 2013 curriculum in learning process (beginning, middle, and ending activity) at the second grade of SMAN 1 Alla' Enrekang.

\section{B. LITERATURE REVIEW}

Sri Andriani (2006) had conducted a research on effectiveness of implementation $\mathrm{CBC}$ to students' mathematic learning achievement. From her research, CBC influenced the improvement of students' mathematic learning achievement by using list of questionnaire and format documentation instrument. Implementation of CBC is in the good category, and students' mathematic learning achievement is in the very good category. While Nurfaizah Siti (2009) had conducted a research on effectiveness of implementation KTSP to improve students' learning achievement in Biology subject. From her research, KTSP influenced the improvement of students' biology learning achievement by using list of 
Nur Humairatul Ulya A, The Effects of The Implementation of 2013 Curriculum to Students'...

questionnaire, interview guidance and format documentation instrument. Based on the research that she did, it known $\mathrm{t}_{\text {test }}$ was bigger than $\mathrm{t}_{\text {table }}(6.375<0.001)$. Referring from previous related finding, most of the curriculum gave influence to students' learning achievement. In this research the researcher assumes that implementation of the 2013 curriculum can give influence to the learning achievement.

\section{Implementation of the 2013 Curriculum}

\section{a. Curriculum}

The term of curriculum was originally found in the statistics world in Ancient Greece, which comes from the word curir means runners, and curere which means a race. So the curriculum can be defined as the distance that must be taken by runners. According to Good in Ahmad (2012: 18), that curriculum is a general over-all plan of the content or specific materials of instruction that the school should offer the student by way of qualifying him for graduation or certification or for entrance into a professional or vocational field. Whereas Taba in Fadlillah (2014: 15) said that a curriculum is a plan for learning; therefore, what is known about learning process and the development of the individual has bearing on the shaping of a curriculum. Then, in modern concept, Romine in Hamalik (2008: 4), said that curriculum is interpreted to mean all of the organized courses, activities, and experiences which pupils have under direction of the school, whether in the class or not.

\section{b. The 2013 Curriculum}

The 2013 Curriculum is a new curriculum that implemented in academic year 2013/2014. This curriculum is the development of previous either CBC and KTSP. However, the emphasis in this curriculum are the increase and the balance of soft skill and hard skill that include aspects of attitudes, skills, and knowledge. Based on Permendikbud No. 81 A in 2013, Learning process according to 2013 curriculum is a educational process that opportunity to students to be able to developing all of their potential that more long time more increase that can indicate in aspects attitude (affective), knowledge (cognitive), and skills (psychomotor). In the 2013 curriculum, learning activity is student center or in this case famous with scientific approach. The students are expected to find out about the learning material and the teacher as facilitator. While assessment process not only the final result but the process to get the result also is assessment. 


\section{Implementation of curriculum}

\section{a. Curriculum implementation model}

Curriculum implementation models proposed by these scholars reflect their approaches to understanding the problems and challenges embedded in the implementation process. They designed their models based on their own individual contexts on key factors or themes. Fullan and Stiegelbauer in Ahmad identify three sets of interactive factors affecting implementation. The first factor is change. They argue that the extent of the required change itself, in terms of actual need for change as well as how clear, complex, and practical the change is, plays a role in whether the implementation is successful or not. The second factor is that of the local characteristics, specifically, which district, community, principal, and teacher are involved in the change process. The third factor is the extent to which government and educational agencies exert their influence on the other stakeholders.

\section{b. Factors affecting the curriculum implementation}

1) External factors

External factor are factors that stem from outside the classroom, such as cultural, organization, or administrative characteristics that teacher and students have little or no control over.

a) Testing

Examinations or high-stakes tests exert a considerable impact on what, and how, the teaching and learning are conducted in the classroom. (Ahmad, 2012: 125).

b) Textbooks

In the EFL context of Indonesia, textbook occasionally represent the syllabus and dictate what should be taught in the classrooms. Text book are believed to have a positive impact on teachers and their classroom teaching during curriculum implementation (Ahmad, 2012: 128)

c) Teacher Training

In order that curriculum policy is interpreted into practice and to ensure that successful implementation and continuity of any curriculum innovation exists in the classroom, it is paramount that teachers receive in-service training and provision of ongoing support and professional development.

d) Resource Support

$\mathrm{Li}$ in Ahmad said that resource support in term of human, material, and financial has been considered indispensable in determining the successful implementation of an innovation. 
Nur Humairatul Ulya A, The Effects of The Implementation of 2013 Curriculum to Students'...

\section{2) Internal factors}

Internal factors related to teachers and students in the classroom. Because teachers are ultimately held responsible for implementation, the review of literature focuses on teachers-related factors such as teachers' beliefs, perceptions, and their understanding and ownership of curriculum innovation. In addition, it is recognized that students-related factors are thus important in the change and innovation literature; however, they are not touched upon in this review because they are outside the scope of the current study.

a) Teacher's Belief in decision Making and Innovation

Teachers' belief have been described by Kangan as 'tacit, often unconsciously held assumptions about students, classrooms, and the academic material to be taught”. (Ahmad, 2012: 135).

b) Teachers' Perceptions on Reform

Teacher change, particularly changes in their perspectives towards reform or innovation, has been considered crucial in promoting successful curriculum implementation in the classroom. Example of teachers' perception towards curriculum innovation can be seen in the English language teaching field in the ELF context, where language teachers teaching approach but feel either reluctant, or incapable of implementing it in their classrooms. Their seemingly contradictory perceptions toward learner-centered communicative curricula have been discussed in a number of studies in Indonesia and other Asian countries.

c) Teacher' knowledge, Understanding, and Ownership of innovation

Gross claimed that the first major barrier to the implementation was that "teachers never obtained a clear understanding of the innovation" (Ahmad, 2012: 146). Not only is teachers' understanding of an innovation essential in curriculum policy and its implementation, teachers' ownership of the innovation is also indispensable. Ownership, the extent to which an innovation belongs to the implementers, exerts a considerable impact on whether an innovation is actually implemented, rather than simply staying at the surface level. (Ahmad, 2012: 147).

\section{Learning Achievement}

\section{a. Definition of Learning}

Learning is a process activity and that very fundamental element in the enforcement stage in education. Shah in Jihad stated that learning is phase of change student behavior that relatively positive and steady as a result of interaction with the environment that involve cognitive processes. According Sudjana in Jihad, learning is 
a process that is characterized by a change in a person, changes as a result of the learning process can be demonstrated in a variety of different forms such as changes in knowledge, understanding, attitudes and behavior, skills, proficiency, validity, and changes in the domains of aspects that exist in individuals who learn. Furthermore According to Slameto learning is a process that does by someone to get a change of new behavior as the result of the experience in interaction with the environment. From that definition the researcher conclude that learning is a process that do by someone to get a change the behavioral in his life.

\section{b. Characteristic of learning}

Slameto gives characteristics about changes of behavior in learning they are:

1) There is consciously

2) As a continuous and functional

3) As a positive and active

4) Not temporary

5) Aims and targeted

6) Includes all aspects of behavior

\section{c. Definition of learning achievement}

Learning achievement is the ability of the child after learning activities. Learning itself is a process of someone trying to obtain a form of behavior that is relatively settled. According to Mulyasa (2006), learning achievement is learning student performance that become indicator basic competence and changes of behavior degree. Keller (Mulyono, 2003) said that learning achievement is attitude that directed to finishing the learning task. According to A. J. Romizowski learning achievement is output of a system input processing. Input from the system in the form of a variety of information while the output is a change in performance or performance. Whereas Hamalik (2008) learning achievement is as happen of the changes the behavior in individual that able to control and measure the knowledge, attitude, and skill form. From that definition, the researcher conclude that learning achievement is the result that students acquired after do leaning and teaching process. 
Nur Humairatul Ulya A, The Effects of The Implementation of 2013 Curriculum to Students'...

\section{RESEARCH METHOD}

\section{Research Design}

This research used descriptive research design. Descriptive research is research that intended to explore the situation, condition or something that related (Arikunto, 2013: 3).

\section{Population and Sample}

\section{a. Population}

Population is the generalization area that consists of object and subject that have certain quality and character, that is chosen by the researcher to study and taken the conclusion (Sugiyono 2013: 117). Population in this research was all of the second grade students of SMA Negeri 1 Alla', that consist of 9 classes that divide into two, MIA (Matematika dan Ilmu Alam) and IIS (Ilmu-Ilmu Sosial). The population in this research was 261 students.

\section{b. Sample}

Sample is part of the population that can represent the research. Technique sampling in this research was cluster sampling. From the 9 classes the researcher took $20 \%$ of the population. So there were two classes that be a sample. To determine the classes, the researcher used random sampling. So, sample in this research were MIA 1 and IIS 2 that consist of 59 students.

\section{Research Instrument}

Research Instrument is tool that is used in the research to filter the information. So that, research instruments in this research are:

\section{a. Observation sheet}

Marshall in Sugiyono (2013) said that, trough observation, the researcher learns about behavior and the meaning attached to those behaviors. In this research, the researcher used participant observation, where the researcher entangles in the activity of the object that is researched. Susan in Sugiyono (2013) said that in participant observation, the researcher observes what people do, listen to what they say, and participates in their activities. In this research, the researcher used passive participant, means the research was present at the scene of action but did not interact or participate.

\section{b. List of questionnaire}

The questionnaire consists of writing questions or statement, to give certain information to the researcher. The questionnaire used in this research was close 
questionnaire where the researcher provided the answers so the respondents just chose the answer. The questions of this questionnaire were related to the 2013 curriculum and the English students' Learning Achievement. This was used to obtain more information about curriculum.

\section{c. Format documentation}

Documentation is used to get the direct data from the research included learning achievement, the relevant books, policy of the school, and etc. The documentation here was used to obtain data about the students' English learning achievement.

\section{Procedure of Collecting Data}

The procedures follow the steps as below:

a. The first, the researcher observed the learning process in the class.

b. Second, the researcher gave the questionnaire to the students to obtain more information about implementation of 2013 curriculum.

c. The researcher gave instruction the way to fill the questionnaire.

d. Next, the researcher took the students' English learning achievement by using format documentation.

e. The researcher analyzed the result by using same formula.

\section{Technique Analysis of Data}

Data that obtained from the sample through the instrument selected by the researcher was used to answer the research problem statements. Therefore, the data needs to be studied and analyzed in order to have meaning in order to solve the problem. In analyzing the data, the researcher employed these steps:

a. Observation, data that got by observation was processed by qualitative, it was data collection, data reduction, data display, and verifying.

b. Calculating the students answer from the questionnaire with the following formula

Percentage: $\mathrm{P}=\frac{f}{N} \times 100 \%$

Where: $\quad \mathrm{P}=$ percentage

$\mathrm{F}=$ frequency

$\mathrm{N}=$ total number of students

c. Using table frequency to know the implementation of the 2013 curriculum and students' learning achievement

1) Interval class

$\mathrm{K}=1+3.3 \log n$

Note: $\mathrm{n}=$ total sample 
Nur Humairatul Ulya A, The Effects of The Implementation of 2013 Curriculum to Students'...

2) Range data

$\mathrm{R}=\mathrm{Xt}-\mathrm{Xr}$

Note: $\mathrm{Xt}=\max$ data

$$
\mathrm{Xr}=\min \mathrm{data}
$$

3) Class Length

$\mathrm{P}=\frac{\mathrm{R}}{\mathrm{K}}$

Note: $\mathrm{R}=$ range

$$
\mathrm{K}=\text { total class }
$$

4) Finding mean score by using the formula below:

$$
\mathrm{X}=\frac{\sum X}{N}
$$

Where: $\mathrm{X}=$ mean score

$\sum X \quad=$ the sum of all scores

$\mathrm{N} \quad=$ the total numbers of students

Finding standard deviation by using the formula below:

$$
\mathrm{SD}=\sqrt{\frac{\sum X^{2}-\frac{\left(\sum X\right) 2}{N}}{N-1}}
$$

Where: $\mathrm{SD}=$ standard deviation

$$
\sum=\text { total row score }
$$

d. To find out the difference between students' learning achievement in using the 2013 curriculum and KTSP the researcher using the following formula:

$\mathrm{t}_{\text {test }}=$

$$
\frac{\overline{\mathrm{X}}_{1}-\mathrm{X}_{2}}{\sqrt{\frac{\left(n_{1}-1\right) \mathrm{S}_{1}^{2}+\left(\mathrm{n}_{1}-1\right) \mathrm{S}_{2}^{2}}{n_{1}+n_{2}-2}\left(\frac{1}{n_{1}}+\frac{1}{n 2}\right)}}
$$

notation:

$$
\begin{array}{ll}
\frac{\mathrm{n}_{1}}{\mathrm{X}_{1}} \text { and } \mathrm{n}_{2} & =\text { sample total } \\
\frac{\mathrm{X}_{2}}{\mathrm{~S}_{1}} & =\text { mean the first sample } \\
\mathrm{S}_{2} & =\text { mean the second sample } \\
\mathrm{S}_{1} & =\text { standard deviation first sample } \\
\mathrm{S}_{2} & =\text { variant the first sample } \\
& =\text { variant the second sample }
\end{array}
$$

\section{D.FINDING AND DISCUSSION}

\section{Finding}

a. Implementation of 2013 curriculum in the learning process at the second grade of SMAN 1 Alla' 
To know how the implementation of 2013 curriculum in the second grade at SMAN 1 Alla' Enrekang, the researcher used observation and questionnaire.

b. Observation

The researcher conducted observation to know how the implementation of 2013 curriculum in the learning process. So, the researcher observed in the class when the learning process was running. It can be seen from the table below:

1) First observation

Place : SMAN 1 Alla' Enrekang

Day/ Date/ Time : Monday, 16-02-2015 / 12.30-14.00

Object : XI MIA 1

Teacher : A

Meeting : First meeting

Material $\quad$ : KD. 3.7 and KD. 4.11 Passive Voice

\begin{tabular}{lll}
\hline No. & \multicolumn{1}{c}{ Steps } & Observer Comment \\
\hline 1 & $\begin{array}{l}\text { Beginning } \\
\text { activity }\end{array}$ & $\begin{array}{l}\text { The opening activity was running well, where the } \\
\text { teacher took the attention of the students to make } \\
\text { them interested in the beginning of learning. } \\
\text { Observer comment } \\
\text { (observation) }\end{array}$ \\
& $\begin{array}{l}\text { In this activity, the teacher had been carrying out her } \\
\text { job well, where teacher guided the students to find out } \\
\text { the passive voice sentences. In addition, teacher also } \\
\text { provoked students to take a few sentences that given } \\
\text { by the teachers while the students themselves were } \\
\text { quite active in the classroom by paying close attention } \\
\text { to the example of the sentences that given and look for } \\
\text { characteristics of passive voice sentences. } \\
\text { Observer comment } \\
\text { (questioning) }\end{array}$ \\
&
\end{tabular}

The way such the teacher conducted, the students became curious and questioning some things. Not all the students active in this class, there were only a few who asked.

Observer comment

(collecting information) 
Nur Humairatul Ulya A, The Effects of The Implementation of 2013 Curriculum to Students'...

In this activity, the students quickly explored the information about the passive voice because star with example in sentences.

3 Ending Activity

\section{Observer comment}

This activity came because of the time not enough until the core activity finish, so the learning came to the closing and the students were given an assignment that related to the material.

2) Second observation

Place : SMAN 1 Alla' Enrekang

Day/ Date/ Time : Monday, 23-02-2015 / 12.30-1400

Object : XI MIA 1

Teacher : A

Meeting : Second meeting

Material : KD. 3.7 and KD. 4.11 Passive Voice

\begin{tabular}{|c|c|c|}
\hline No. & Steps & Observer Comment \\
\hline 1 & $\begin{array}{l}\text { Beginning } \\
\text { activity }\end{array}$ & $\begin{array}{l}\text { The opening activity was running well, where the teacher } \\
\text { took the attention of the students and also remembering the } \\
\text { students what they learned in the previous meeting. So it } \\
\text { connected with the materials that have been studied. }\end{array}$ \\
\hline \multirow[t]{4}{*}{2} & $\begin{array}{l}\text { Middle } \\
\text { activity }\end{array}$ & $\begin{array}{l}\text { Observer comment } \\
\text { (associating) }\end{array}$ \\
\hline & & $\begin{array}{l}\text { By comparing like the teacher commanded, the students } \\
\text { more understand about the passive sentence, knowing the } \\
\text { difference passive and active in English and Indonesian. }\end{array}$ \\
\hline & & $\begin{array}{l}\text { Observer comment } \\
\text { (communicating) }\end{array}$ \\
\hline & & $\begin{array}{l}\text { In communicating the students did not maximally because } \\
\text { only some students that communicated using passive voice, } \\
\text { in addition, they were supposed to be creative with the } \\
\text { scientific literature by using the passive voice. }\end{array}$ \\
\hline 3 & $\begin{array}{l}\text { Ending } \\
\text { Activity }\end{array}$ & Observer comment \\
\hline
\end{tabular}


Closing activity was running well, where the students summarized the material, the teacher also gave assignment. It can be a way to make the students study at home.

3) Third observation

$\begin{array}{ll}\text { Place } & \text { : SMAN 1 Alla' Enrekang } \\ \text { Day/ Date/ Time } & : \text { Monday, 16-02-2015/ 12.30-14.00 } \\ \text { Object } & : \text { XI IIS 2 } \\ \text { Teacher } & : \text { B } \\ \text { Meeting } & : \text { First meeting } \\ \text { Material } & : \text { KD. 3.7 and KD. 4.11 Passive Voice }\end{array}$

\begin{tabular}{|c|c|c|}
\hline No. & Steps & Observer Comment \\
\hline 1 & $\begin{array}{l}\text { Beginning } \\
\text { activity }\end{array}$ & $\begin{array}{l}\text { The opening activity was running well, where the teacher } \\
\text { took the attention of the students to make them } \\
\text { interesting in the beginning of learning, and also the } \\
\text { teacher introduced the material but not direct to the } \\
\text { topic. Furthermore, he also gave information about the } \\
\text { benefit in learning this material. }\end{array}$ \\
\hline \multirow[t]{6}{*}{2} & $\begin{array}{l}\text { Middle } \\
\text { activity }\end{array}$ & $\begin{array}{c}\text { Observer comment } \\
\text { (observation) }\end{array}$ \\
\hline & & $\begin{array}{l}\text { In this activity, the teacher has been carrying out his job } \\
\text { well, where teacher guided the students to find out the } \\
\text { passive voice sentences. In addition, teacher also } \\
\text { provoked students to take a few sentences that given by } \\
\text { the teacher to identify, the students were quite active in } \\
\text { the classroom by paying close attention to the example of } \\
\text { the sentences that given and look for characteristics of } \\
\text { passive voice sentences. }\end{array}$ \\
\hline & & $\begin{array}{c}\text { Observer comment } \\
\text { (questioning) }\end{array}$ \\
\hline & & $\begin{array}{l}\text { The way that conducted by the teacher, the students } \\
\text { become curious and questioning some things. Not all the } \\
\text { students active in this class, there are only a few who } \\
\text { asked. }\end{array}$ \\
\hline & & $\begin{array}{c}\text { Observer comment } \\
\text { (collecting information) }\end{array}$ \\
\hline & & $\begin{array}{l}\text { In this activity, the students quickly explored the } \\
\text { information about the passive voice because done by } \\
\text { working together. }\end{array}$ \\
\hline
\end{tabular}


Nur Humairatul Ulya A, The Effects of The Implementation of 2013 Curriculum to Students'...

\begin{tabular}{|c|c|c|}
\hline \multirow{5}{*}{3} & & $\begin{array}{l}\text { Observer comment } \\
\text { (associating) }\end{array}$ \\
\hline & & $\begin{array}{l}\text { By comparing like this, the students more understand } \\
\text { about the passive sentence. By did exercise, the students } \\
\text { knew about passive voice deeply. } \\
\text { Observer comment } \\
\text { (communicating) }\end{array}$ \\
\hline & & $\begin{array}{l}\text { In communicating the students discussed together about } \\
\text { passive voice, but this activity not maximally where they } \\
\text { were supposed to be creative with the scientific literature } \\
\text { by using the passive voice. }\end{array}$ \\
\hline & \multirow{2}{*}{$\begin{array}{l}\text { Closing } \\
\text { Activity }\end{array}$} & Observer comment \\
\hline & & $\begin{array}{l}\text { The teacher gave the assignment to make his students at } \\
\text { home and it will be discuss in the next meeting. }\end{array}$ \\
\hline
\end{tabular}

4) Fourth observation

$\begin{array}{ll}\text { Place } & \text { : SMAN 1 Alla' Enrekang } \\ \text { Day/ Date/ Time } & \text { : Monday, 16-02-2015 / 12.30-14.00 } \\ \text { Object } & : \text { XI IIS } 2 \\ \text { Teacher } & : \text { B } \\ \text { Meeting } & : \text { Second meeting } \\ \text { Material } & : \text { KD. 3.7 and KD. 4.11 Passive Voice }\end{array}$

\begin{tabular}{|c|c|c|}
\hline No. & Steps & Observer Comment \\
\hline 1 & $\begin{array}{l}\text { Opening } \\
\text { activity }\end{array}$ & $\begin{array}{l}\text { The opening activity was running well, where the teacher } \\
\text { took the attention of the students to make them } \\
\text { interesting in the beginning of learning. The teacher also } \\
\text { refreshed and remained the students what they got in the } \\
\text { previous meeting. }\end{array}$ \\
\hline \multirow[t]{5}{*}{2} & $\begin{array}{l}\text { Body, core } \\
\text { activity }\end{array}$ & $\begin{array}{l}\qquad \begin{array}{l}\text { Observer comment } \\
\text { (observing) }\end{array} \\
\text { In his activity, the teacher discussed the assignment with } \\
\text { the students. It is necessary because the student can know } \\
\text { their answer right or wrong sentences. }\end{array}$ \\
\hline & & Observer comment \\
\hline & & $\begin{array}{l}\text { the students became curious about their answer, whether } \\
\text { it is true or not, and try to answer the questions }\end{array}$ \\
\hline & & $\begin{array}{l}\text { Not all the students active in this class, there were only a } \\
\text { few who want to answer the task }\end{array}$ \\
\hline & & Observer comment \\
\hline
\end{tabular}


In this activity, the students quickly explored the information about the passive voice because they corrected their friends job, and also they knew their incorrectness that they in their assignment.

\section{Observer comment (associating)}

In this case, the teacher explained one number of the students' answer in the white board, and the students pay attention to their teacher while check their answer.

Observer comment (communicating)

In communicating the students discussed about the passive voices, in this case they answer and check if they wrong when doing assignment, furthermore, some of the students asking how come the answer like that, some of the students answered their friends' confuses.

At the end, when the class star crowded, the teacher explained more about the passive voce.

c. Questionnaire

The questionnaire consists of five answers, where the first answer is given score 5, the second answer is given score 4, the third answer is given score 3, the fourth answer is given score 2 , and the fifth answer is given score 1. This data is obtained from 61 students that become respondents. To know how the implementation of 2013 curriculum, the data that acquired by questionnaires is processed by some formula:

1) Interval class

$$
\begin{aligned}
\mathrm{K} & =1+3.3 \log \mathrm{n} \\
& =1+3.3 \log 61 \\
& =6.87 \\
& =7
\end{aligned}
$$

2) Range data

$$
\begin{aligned}
\mathrm{R} & =\mathrm{Xt}-\mathrm{Xr} \\
& =127-87 \\
& =40
\end{aligned}
$$


Nur Humairatul Ulya A, The Effects of The Implementation of 2013 Curriculum to Students'...

3) Class length

$$
\begin{aligned}
\mathrm{P} & =\frac{\mathrm{R}}{\mathrm{K}} \\
& =\frac{40}{7} \\
& =5.71 \\
& =6
\end{aligned}
$$

Table 1. Distribution frequency of questionnaires about implementation of 2013 curriculum

\begin{tabular}{cccc}
\hline No & Interval Class & Tally & Frequency \\
\hline 1 & $124-130$ & III & 3 \\
2 & $117-123$ & IIIII I & 6 \\
3 & $110-116$ & IIIII IIIII I & 11 \\
4 & $103-109$ & IIIII IIIII IIIII IIIII I & 21 \\
5 & $96-102$ & IIIII IIIII I & 11 \\
6 & $89-95$ & IIIII II & 7 \\
7 & $82-88$ & II & 2 \\
\hline
\end{tabular}

4) Mean

$$
\begin{aligned}
\mathrm{Me} & =\frac{\sum \mathrm{fixi}}{\sum f i} \\
& =\frac{6473}{61}=106.11
\end{aligned}
$$

5) Standard Deviation

$$
\begin{aligned}
& \mathrm{S}=\sqrt{\frac{\sum f i(x i-x)^{2}}{n-1}} \\
& \mathrm{~S}=\sqrt{\frac{5830.198}{60}} \\
& \mathrm{~S}=\sqrt{97.17} \\
& \mathrm{~S}=9.86
\end{aligned}
$$

Distribution frequency table of the implementation of 2013 curriculum in SMAN 1 Alla' Enrekang quite varies. The highest score from questionnaire about the implementation of 2013 curriculum is 127 . With a sample number is 61 students, so the highest score of the criterion score is $127 \times 61=7747$. While the number of variable scores of the implementation of 2013 curriculum is based on data collected through questionnaires is 6473. Thereby, the bigness of implementation of the 2013 curriculum is $6473 / 7747=0.84$. If it in the percentage form is $84 \%$ criteria that set. 
Volume I, Number 01, June 2015

\begin{tabular}{cc}
\hline Interval & Predicate \\
\hline $96-100$ & $\mathrm{~A}$ \\
$91-95$ & $\mathrm{~A}^{-}$ \\
$86-90$ & $\mathrm{~B}^{+}$ \\
$81-85$ & $\mathrm{~B}$ \\
$75-80$ & $\mathrm{~B}^{-}$ \\
$70-74$ & $\mathrm{C}^{+}$ \\
$\mathbf{6 5 - 6 9}$ & $\mathrm{C}^{-6}$ \\
$\mathbf{6 0 - 6 4}$ & $\mathrm{C}^{-}$ \\
$55-59$ & $\mathrm{D}^{+}$ \\
$<54$ & $\mathrm{D}^{-5}$ \\
\hline & (Source: www.madematika.com)
\end{tabular}

From the table above shows that the implementation of 2013 curriculum at SMAN 1 Alla' Enrekang is at points 81-85. Therefore it can be concluded that the implementation of 2013 curriculum at SMAN 1 Alla' Enrekang is good.

1) Students' achievements in learning English by using the 2013 curriculum at SMA Negeri 1 Alla' Enerekang

To know the students' achievement in learning English by using 2013 curriculum the researcher using documentation of the students' learning achievement in English. In this case the score of the students obtained, the average can be shown below:

$$
\begin{array}{ll}
\text { Total students } & =61 \text { students } \\
\text { Total score } & =189.33 \\
\text { So, } & \mathrm{X}=\frac{\sum \mathrm{X}}{\mathrm{N}}=\frac{189.33}{61}=3.104
\end{array}
$$

2) Students' achievements in learning English by using KTSP at SMA Negeri 1 Alla' Enrekang.

To know the students' achievement in learning English by using KTSP the researcher used documentation of the students' achievement. In this case the score of the students obtain, it takes from the other class with consideration that their knowledge is relative same. It can be shown below:

$$
\begin{array}{ll}
\text { Total students } & =59 \text { students } \\
\text { Total score } & =189.32 \\
\text { So, } \quad \mathrm{X} & =\frac{\Sigma \mathrm{X}}{\mathrm{N}}=\frac{189.32}{\mathbf{5 9}}=3.209
\end{array}
$$


Nur Humairatul Ulya A, The Effects of The Implementation of 2013 Curriculum to Students'...

\section{3) Differences between students' English learning achievement by using} the 2013 curriculum and students' English learning achievement by using KTSP at SMA Negeri 1 Alla' Enrekang

To see there is differences between students' English learning achievement by using the 2013 curriculum and students' English learning achievement by using KTSP at SMA Negeri 1 Alla' Enrekang, the researcher using $t_{\text {test, }} \mathrm{X}_{1}$ is sample that using the 2013 curriculum and $\mathrm{X}_{2}$ is sample that using KTSP.

$$
\begin{aligned}
& \mathrm{t}_{\text {hitung }}=\frac{\overline{\mathrm{X}_{1}}-\overline{\mathrm{X}_{2}}}{\sqrt{\frac{\mathrm{S}_{1}^{2}}{\mathrm{n}_{1}}+\frac{\mathrm{S}_{2}^{2}}{\mathrm{n} 2}-2 \mathrm{r}\left(\frac{\mathrm{S}_{1}}{\sqrt{\mathrm{n}_{1}}}\right)+\left(\frac{\mathrm{S}_{2}}{\sqrt{\mathrm{n}_{1}}}\right)}} \\
& \overline{\mathrm{X}_{1}}=\frac{\sum \mathrm{X}}{\mathrm{N}}=\frac{189.33}{61}=3.104 \\
& \mathrm{X}_{2}=\frac{\sum \mathrm{X}}{\mathrm{N}}=\frac{189.32}{59}=3.209 \\
& \mathrm{~S}=\sqrt{\frac{\sum \mathrm{X}^{2}-\frac{(\Sigma \mathrm{X})^{2}}{\mathrm{~N}}}{\mathrm{n}-1}}=\sqrt{\frac{589.78-\frac{(189.33)^{2}}{61}}{61-1}} \\
& \text { Where: } \mathrm{S}_{1}=\sqrt{\frac{2.14}{60}} \\
&=0.189 \\
& S_{1}^{2}=0.036 \\
& \mathrm{~S}_{2}=\sqrt{\frac{608.88-\frac{(189.32)^{2}}{59}}{59-1}} \\
& \mathrm{~S}_{2}^{2}=0.024 \\
& \frac{1.39}{58} \\
& 0.154 \\
& 0.024
\end{aligned}
$$

Hypothesis that will be tested based on the different $n, n_{1}=61$ and $n_{2}=59$. But variant both sample homogeny or not, so it is necessary to test the variant homogeneity by $\mathrm{F}_{\text {test. }}$

$$
\mathrm{F}=\frac{\text { biggest variant }}{\text { smallest varian }}=\frac{0.036}{0.024}=1.5
$$

This score then compare with $\mathrm{F}_{\text {table }}$ with $\mathrm{df}$ of numerator $(61-1=60)$ and $\mathrm{df}$ of denominator $(59-1=58)$. Based on that $\mathrm{df}$ and for level significance $5 \%$, so $\mathrm{F}_{\text {table }}=$ 1.52 , fact $\mathrm{F}_{\text {test }}<\mathrm{F}_{\text {table }}(1.5<1.52)$. Thereby it can be said that variant of the two data is homogenous. 
Because $n_{1}$ and $n_{2}$ not same, but the variant is homogenous, so the $t_{\text {test }}$ is pollen variant formula:

$$
\begin{aligned}
\mathrm{t}_{\text {test }}= & \frac{\mathrm{X}_{1}-\mathrm{X}_{2}}{\sqrt{\frac{\left(n_{1}-1\right) \mathrm{S}_{1}^{2}+\left(\mathrm{n}_{1}-1\right) \mathrm{S}_{2}^{2}}{n_{1}+n_{2}-2}\left(\frac{1}{n_{1}}+\frac{1}{n 2}\right)}} \\
& =\frac{3.104-3.209}{\sqrt{\frac{(61-1) 0.039+(59-1) 0.024}{61+59-2}\left(\frac{1}{61}+\frac{1}{59}\right)}} \\
& =\frac{-0.105}{\sqrt{0.03163(0.03334)}} \\
= & -2.692
\end{aligned}
$$

Level of significance $(@)=0.05$

Degree of freedom $(\mathrm{df})=\mathrm{n}_{1}+\mathrm{n}_{2}-2=61+59-2=118$

$\mathrm{t}_{\text {table }}=1.960$

$\mathrm{t}_{\text {test }}=-2.692$

if $\mathrm{t}_{\text {test }}<\mathrm{t}_{\text {table }}$ so $\mathrm{H}_{\mathrm{o}}$ acceptable and $\mathrm{H}_{\mathrm{a}}$ unacceptable

fact: $-1.960<-0.34<1.960$, so $\mathrm{H}_{0}$ acceptable and $\mathrm{H}_{\mathrm{a}}$ unacceptable

conclusion, there is no differences between students' English learning achievement by using the 2013 curriculum and students' English learning achievement by using KTSP at SMA Negeri 1 Alla' Enrekang.

\section{Discussion}

The 2013 Curriculum is a curriculum that uses a scientific approach where the students do actively in the learning process that emphasizes on the process of observing, questioning, collecting information, associating, and communicating that focuses on the increase and the balance of soft skills and hard skills that consist of cognitive, affective, and psychomotor aspects.

Based on data that obtained from research using observation and questionnaire, it ascertainable the implementation of the 2013 curriculum at SMAN 1 Alla' Enrekang, while data obtained through documentation showed how the students' learning achievement by using the 2013 curriculum and KTSP, and $t_{\text {test }}$ to see the differences the students' learning achievement by using the 2013 curriculum and KTSP.

To know the implementation of 2013 curriculum, from observation, it appears that the implementation of the 2013 curriculum in the learning process has been good. Where learning activities were in accordance with the existing syllabus, in addition the students active in the classroom by using a scientific approach included activities of observing, questioning, collecting information, associating, communicating. Observation that the researcher conducted was observing two 
Nur Humairatul Ulya A, The Effects of The Implementation of 2013 Curriculum to Students'...

classes. The implementation of the 2013 curriculum, better or not, was depend on the teacher. From the observation that researcher did, the teacher A did not maximally in implementing this curriculum. It can be seen from the activities that the teacher and the students did, there was not time management. The opening and closing activities were running well but the core activity was not maximally. The core activity stopped because of the time was over and will be continued in the next meeting. These activity should be not separated (observing, questioning, collecting information, associating and communicating), because they were part of implementation the 2013 curriculum especially in core activity. Indeed the students' active in the class, but their affective was not good. According to Fadlillah the 2013 curriculum is balance between soft skills and hard skills. Different from teacher B, he more understand about the 2013 curriculum, it can be seen from opening, core, and closing activity was running well. As a note, the teacher B sometimes made a joke when the students confusing or boring. Teacher B was more interesting and mastering the 2013 curriculum.

To strengthen the data that researcher obtained, it can be seen also from the results of questionnaire. In data that obtained through the questionnaire was analyzed by using percentage formula. This analysis showed that the implementation of 2013 curriculum on average located 81-85. This indicates that the 2013 curriculum at SMAN 1 Alla' in its implementation has been good. This questionnaire was from students' point of view about the implementation of the 2013 curriculum, so the data not only from the researcher view, but also from the students. In fact, both the researcher view and the students view were same.

To determine the students' learning achievement the researcher using documentation, in this case the researcher took data from students' learning achievement using the curriculum in 2013 and students using the KTSP. To see the difference of them, the researcher used the $t_{\text {test }}$. In $t_{\text {test }}$ result showed there was no difference between students' learning achievement using the 2013 curriculum with students' learning achievement using KTSP. It can be seen from the $t_{\text {test }}$ performed that $\mathrm{t}_{\text {test }}=-2.692$ while $\mathrm{T}_{\text {table }}=1.960$. If $\mathrm{t}_{\text {table }}$ is greater than the $\mathrm{t}_{\text {test }}$ it can be said that there is no difference between them.

From the collected data it can be known that the implementation of 2013 curriculum does not influence the students' learning achievement at SMAN 1 Alla', so it does not give effect in improving students' learning achievement. Indeed, in the KTSP the students' learning achievement is good.

From the researcher point of view that it happen because the 2013 curriculum is a new curriculum, only some schools that using it, and the school who 
use it, just as a testing this curriculum. In fact for one year of running this curriculum, it does not give effect to the students' learning achievement. Although the 2013 curriculum does not give effects to the students' learning achievement, it cannot conclude that the 2013 curriculum does not give effects in every aspect of students' ability (affective, psychomotor and cognitive). In this research, the psychomotor aspect is very good, where the students actively in the class during the learning process. In other words, the learning achievement was not only influenced by the curriculum.

In conclusion, the 2013 curriculum in concept is very good, where the students more actively in the class and explore their knowledge but it need more socialization to the teachers and to the other schools. In the future, the 2013 curriculum will be implemented well.

\section{E. CONCLUSION}

The students' learning achievement was not influenced by the curriculum. It can be seen from the data, although it was from different curriculum, the average of the learning achievement was same. It indicates that not only curriculum that effect the students' learning achievement but also many other factors.

\section{F. RECOMMENDATION}

Based on the result of the data analysis, the researcher puts forward some suggestions as follows:

1. The teacher should master the 2013 curriculum especially in the learning process because it can determine the learning achievement of the students when it mater maximally.

2. The government should do more socialization of this curriculum to the every school.

3. For the other schools, they have to use the 2013 curriculum because this curriculum has a very good concept.

\section{BIBLIOGRAPHY}

Ahmad, Djuwairiyah. Curriculum Reform. Makassar: Allauddin University press, 2012.

Andriani, Sri. "Efectivitas Penerapan Kurikulum Berbasis Kompetensi Terhadap Peningkatan Hasil Belajar Matetmatika Siswa Kelas VIII Pada SMP Negeri 2 Baraka Kabupaten Enrekang". Skripsi. Makassar: Fakultas Tarbiyah dan Keguruan UIN Alauddin, 2006. 
Nur Humairatul Ulya A, The Effects of The Implementation of 2013 Curriculum to Students'...

Anonim. "Konversi Nilai Kurikulum 2013, Mana yang dipakai". Online. http:/ /www.madematika.com/2014/05/konversi-nilai-kurikulum-2013mana-yang.html (April 22, 2015)

Arikunto, Suharsimi. Prosedur Penelitian. Jakarta: Rineka Cipta, 2013.

Daryanto. Evaluasi Pendidikan. Jakarta: PT Rineka Cipta, 2007.

Djaali. Psikologi Pendidikan. Jakarta: Bumi Aksara, 2008.

Fadlillah. Implementasi Kurikulum 2013. Yogyakarta: Ar-Ruzz Media, 2014.

Gay, L.R. Educational Research; Competencies for Analysis and Application. U.S.A: Charles E. Merrill Publishing co.

Hamalik, Oemar. Dasar-dasar Pengembangan Kurikulum. Bandung: Rosda, 2008.

Hidayat, Sholeh. Pengembangan Kurikulum Baru. Bandung: Rosda, 2013.

Idi, Abdullah. Pengembangan Kurikulum Teori dan Praktek. Jogjakarta: Ar-Ruzz Media, 2007.

Jihad, Asep dan Abdul Haris. Evaluasi Pembelajaran. Yogyakarta: Multi Pressindo, 2013.

Kurasih, Imas dan Berlin Sani. Sukses Mengimplementasikan Kurikulum 2013. Jakarta: Kata Pena, 2014.

-------, Metode Penelitian Pendidkan. Bandung: Alfabeta, 2013.

Nurdin, Syafruddin. Guru Profesional dan Implementasi Kurikulum. Jakarta: Quantum Teaching, 2005.

Nurfaizah, Siti. "Efectivitas Penerapan Kurikulum Tingkat Satuan Pendidikan Terhadap Hasil Belajar Siswa Pada Mata Pelajaran Biologi Kelas XI IPA MAN 2 Model Makassar". Skripsi. Makassar: Fakultas Tarbiyah dan Keguruan UIN Alauddin, 2009.

Riduwan. Dasar-Dasar Statistika. Bandung: Alfabeta, 2003.

Sanjaya, Wina. Strategi Pembelajaran Berorientasi Standar Proses Pendidikan. Jakarta: Kencana, 2008.

Saprin. Korelasi Antara Berpikir Ilmaiah dengan Prestasi Belajar Akademik. Makassar: Alauddin University Press, 2012.

Sugiyono. Metode Penelitian Kombinasi (Mixed Methods). Bandung: Alfabeta, 2014.

Suryabrata, Sumadi. Metodology Penelitian. Jakarta: PT. RajaGrafindoPersada, 2003.

Universitas Islam Negeri Alauddin Makassar. Pediman Penulisan Karya Tulis Ilmiah. Makassar: Alauddin Press, 2014. 